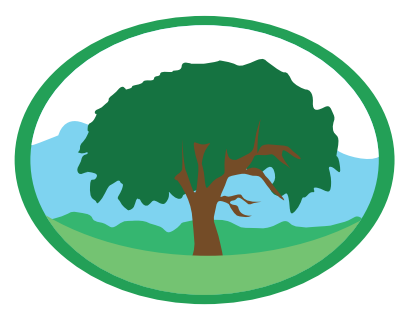

\title{
The use of questionnaires for assessment of customer's needs in seeds laboratories
}

Vergara, Rafael de Oliveira*; Gadotti, Gizele Ingrid ${ }^{2}$; dos Reis, Ângelo Vieira ${ }^{3}$.

'Master degree student, Graduate Program Seed Science and Technology, Campus Capão do Leão - Universidade Federal de Pelotas, Capão do Leão, RS, Brazil,. Email: agrorafaelvergaraldgmail.com

${ }^{2}$ Prof. Dr., Engineering Center, Universidade Federal de Pelotas.

${ }^{3}$ Prof. Dr., Rural Departament, Agronomy School “EliseuMaciel”, Universidade Federal de Pelotas.

Keywords: quality control, life cycle, analyze seeds \section{A utilização de questionários para avaliação das necessidades dos clientes em laboratório de sementes}

Palavras-chave: controle de qualidade, ciclo de vida, análise de sementes

\begin{abstract}
Use of questionnaires is usual in the identification of
Abstract
Use of questionnaires is usual in the identification of customer's needs. Identifying these needs is made with the aid of literature, analysis of similar technical systems, consulting experts, using simulations and a questionnaire to product customers. This work is not an evaluation of product, but of a service. The life cycle concept is widely used for product design, but does not have a use for services because its characterization is different. Therefore the objective of this study is to incorporate the concept of life cycle and questionnaires in a service such as a seeds laboratory, in order to make more precise mapping of needs and wishes of customers. Thus, identification of internal and external customers, identifying life cycle of seed samples, to a questionnaire on the needs and apply it to customers identified earlier in the process. The results showed that: seed laboratory life cycle is an efficient tool for identifying customer's needs; the methodology of questionnaires should be used more often as a management tool; $24 \%$ customers are dissatisfied with the emission test results.
\end{abstract}

\section{Resumo}

0 uso de questionários é habitual na identificação das necessidades do cliente. Essa identificação é feita com o auxílio de literatura, análise de técnicas semelhantes, consulta a especialistas, usando simulações e um questionário aos clientes. Este trabalho não é uma avaliação do produto, mas de um serviço. 0 conceito de ciclo de vida é amplamente utilizado para a concepção dos produtos, mas não tem um uso para serviços porque a sua caracterização é diferente. Portanto, o objetivo deste estudo é incorporar o conceito de ciclo de vida e questionários em um serviço como um laboratório de sementes, a fim de fazer um mapeamento mais preciso das necessidades e desejos dos clientes. 
Assim, a identificação dos clientes internos e externos, identificando ciclo de vida de amostras de sementes, fazer um questionário sobre as necessidades e aplicálo a clientes identificados anteriormente no processo. Os resultados mostraram que: ciclo de vida do laboratório de sementes é uma ferramenta eficiente para a identificação das necessidades do cliente; e a metodologia de questionários deve ser utilizada com mais frequência como uma ferramenta de gestão; $24 \%$ dos clientes estão insatisfeitos com os resultados de ensaios de emissões.

\section{INTRODUCTION}

\subsection{Customer's needs}

Implementation of quality systems in testing laboratories is an initiative relatively recent and adopted mainly to facilitate the international exchange of goods or supplies through the mutual recognition of studies on their characteristics, carried out by laboratory tests in different countries guided by common standards (LOURO et al., 2002). Agricultural area, especially seeds area is no exception.

Management of a laboratory is currently based on the use of standards such as, in Brazil, ABNT ISO / IEC 17025:2005. According to Louro et al. (2002) this is a way to use the loyalty of current customers to acquire new clientele, since the accreditation confirms and recognizes the technical competence of the laboratory to produce technically valid results, which increases its credibility in the market.

According to Juran (1989), to make any change in behavior or in the process to increase satisfaction with a product or a service, it is necessary to identify customers, or anyone who is affected by it. Once you have identified who are the customers, you must also identify their needs and what they expect from the product or service.

\subsection{Seed laboratory}

A seed laboratory (SL) can be considered a quality control center, whose main function is to provide support for standardization of processes, based on recognized techniques, in the system of seed production in all its phases: sowing, harvesting, processing, treatment, storage until its commercialization (CARVALHO; NAKAGAWA, 1998).

The same authors reported that the seed laboratory provides a safe way to ensure that the genetic characteristics obtained by the breeder and maintained during the multiplication in the field are properly evaluated. The laboratory has a mission to make physiological analysis and health quality of seed samples, with the correct interpretation of the results, given the analysis of patterns of seeds required. The activity of seed laboratories should be seen as a dynamic activity, which is constantly changing, both by the improvement of the means available for assessing the quality of seeds as the incorporation of new analytical methods.

\subsection{Use of questionnaires}

Use of questionnaires is common in the identification of customer's needs. Reis;Forcelini (2006) recommend the use of questionnaires in the early stages of product design (informational design), which consists of detailed analysis of the design problem, seeking all the information necessary for full understanding of the problem. Design specifications are derived from the needs and desires of customers for the product. Identifying these needs is made with the aid of literature, analysis of similar technical systems, consulting experts, using simulations and a questionnaire to customers of the product. The present work is not an evaluation of the product itself, but of a service.

\subsection{Life cycle}

A new product is launched, it is further developed, reaches maturity, decline and eventually disappears. This is the essence of the concept of product life cycle as devised by Pessoa; Martins (2007). Westkämpera at al. (2000) consider the product life cycle as a whole and optimizes the interaction of product design, manufacturing and life cycle activities. The goal of this approach is to protect resources and maximize the effectiveness during usage.

This study has focus of a service in a seed laboratory and the link between product and service is based on the idea of previous authors that a product and service have similar characteristics, as new products are similar to a new service demand. Similarly, for evaluation of products and services the opinion of the different 
customers involved must to be assessed in someway.

Reis;Forcelini (2006) said one of the results of the life cycle analysis is to obtain the customer's needs for design purposes. These authors propose a set of guidelines to support the collection and systematization of design needs through a survey, as:

a. Establishing the stages of product life cycle as a basis of design information;

b. Defining the clients of the project according to the phases of the life cycle;

c. Preparing questions for each client in accordance with relevant issues at each stage of product life cycle.

\subsection{Objective}

In order to be more efficient and verifying the effectiveness of the concept of life cycle based on questionnaires responses, the aim of this work is to incorporate the concept of life cycle service with the purpose of making more accurate assessment of needs and desires of customers in a seed lab.

Specific objectives were proposed such as: identifying the life cycle of a seed sample; also, identifying the internal and external customers of the procedure of a seed laboratory; writing and applying a questionnaire on customer's needs based on life cycle; and finally, access the needs and desires of internal and external customers.

\section{MATERIAL AND METHODS}

The methodology used was that of Reis; Forcelini(2006) according to the sequence of Figure1. The questionnaire had 14 multiple-choice questions.

The form of the questionnaire was implemented in Google Doc's ${ }^{\circledR}$ and it was sent to SL's customers in Brazil.

At first, the life cycle of a seed laboratory (seed sample)was identified based on the responsibilities matrix of the laboratory. After, customers were identified for each stage of life cycle. Customer's needs were identified at each stage of the cycle and the survey was conducted. Customer's needs were identified through visiting laboratories, questioning technician in charge and expert people in this area.

More details with respect to keeping the focus in the scope of the problem and formulation of proper
Figure 1. Steps and tasks of the methodology employed by Reis and Forcelini (2006) to obtain customer requirements.

Search for information about the design theme

- establishing the life cycle of the product;

- search for technical information.

\begin{tabular}{|c|c|}
\hline & $\begin{array}{l}\text { Bibliographic search } \\
\text { Similar systems analysis. }\end{array}$ \\
\hline \multicolumn{2}{|c|}{$\begin{array}{l}\text { Identify customer's needs } \\
\text { - define the customers throughout the project life } \\
\text { cycle of the product; } \\
\text { - collecting customer's needs. }\end{array}$} \\
\hline & $\begin{array}{l}\text { Bibliographic search; } \\
\text { Similar systems; } \\
\text { Consulting experts; } \\
\text { Questionnaire; } \\
\text { Simulations of use. }\end{array}$ \\
\hline \multicolumn{2}{|c|}{$\begin{array}{l}\text { Establish customer's requirements } \\
\text { - analyze customer needs. }\end{array}$} \\
\hline & $\begin{array}{l}\text { Checklists; } \\
\text { Brainstorms. }\end{array}$ \\
\hline \multicolumn{2}{|c|}{ List of requirements } \\
\hline
\end{tabular}

questions may be seen in Reis et al. (2003). On this topic Sudman;Bradburn (1982) present a summary of precautions to be observed in the questions.

The form of the questionnaire was implemented in Google Doc's ${ }^{\circledR}$ and forwarded to 577 seed breeders affiliated with ABRASEM (Seeds and Seedlings Brazilian Association), seven official laboratories of Ministry of Agriculture, Livestock and Supply (MAPA), and 57 postgraduates students in this field. It is important to note that more than a half of the messages sent returned due to invalid e-mail addresses, describing that the data bank used was not updated, so they were considered just 360 answers. Also,itwas observedthat not all of seed breeders have seed labs, but they often ask for this service outside of their companies.

The data analysis was performed by Google Doc's structure.

\section{RESULTS AND DISCUSSION}

The result of SL life cycle is represented by the 
flowchart in Figure 2.

Based on the flowchart, Figure 2, customers were identified and categorized as internal and external to SL. The class of intermediate client was disregarded due to peculiarities of this service.

Thus, the internal customers considered were:
a. Laboratory technicians;
b. Technicians in charge;
c. Students.

External customers were separated as:
a. Teachers;
b. Students;
c. Seed farmers;
d. Grain farmers.

Issues of interest were drawn up based on the life cycle and on the potential customers. This allowed knowing in the advance the answers needed in each stage of life cycle and, therefore the questions to be made, as shown in Figure 3. It was easy to identify customers and their needs based in life cycle and its methodology. This methodology made the study easier, because there was a logical way to identify information.

With this detailed information obtained from the SL life cycle and the analysis presented in Figure 3 a questionnaire was designed.

A return rate of $5.83 \%$ (21 forms) was achieved after one month. This is below the rate found by Reis; Forcelini (2006) that had $43.9 \%$ of respondents to the forms sent by e-mail; Sudman;Bradburn (1982) state that rates above $10 \%$ may be considered excellent.

Although $5.83 \%$ may seem a low rate of return, it was considered a regular data because it was the first time that this kind of customers have heard about this methodology. In Brazil, Rural people are conservative. They preferred to hear from a pioneer first and after to search about the issue and have their answers. Methodology of questionnaire is seldom used in seeds area. However several studies could be handling with this way, as in the introduction of quality system in seed area the use of this methodology need to be increased.

Questionnaire was answered in the first fifteen days after it was sent.

The profile of respondents was based on the first
Figure 2. Flowchart of a seed laboratory process and its customers

Sample reception

- Laboratory technicians

Sample data

- Laboratory technicians

Analytical Setor

- Laboratory technicians/students

Germination

- Laboratory technicians/students

Storage and discard

- Laboratory technicians/technician in charge

Critical analysis

- Technician in charge

Results

- Students/farmers

Figure 3. Information to be collected in the stages of SL life cycle

\begin{tabular}{|c|c|}
\hline Life cicle & Information to be collected \\
\hline Reception & Client's profile \\
\hline Sample data & $\begin{array}{l}\text { Problems in sample identification } \\
\text { Traceability }\end{array}$ \\
\hline Sample prepare & $\begin{array}{l}\text { Storage local } \\
\text { Manual or automated }\end{array}$ \\
\hline \multirow[t]{2}{*}{ Analytical setor } & Technician $\mathrm{x}$ training \\
\hline & $\begin{array}{l}\text { Analysis of scope } \\
\text { Critical points }\end{array}$ \\
\hline Germination & Equipments accuracy \\
\hline Storage and disposal & $\begin{array}{l}\text { Storage local } \\
\text { Time until to disposal }\end{array}$ \\
\hline Crytical analysis & $\begin{array}{l}\text { Disposal site } \\
\text { Criterion used }\end{array}$ \\
\hline Results emission & Ermission time \\
\hline
\end{tabular}

quiz question and has the characteristic of being, in most cases, seed producers and technical managers / technician in charge, Figure 4. It is important to note that teachers and grain farmers are not on focus. The focus is seed farmers and technicians in charge on seed 
farmers.

Figure 4. Stratification of answers by class of respondents

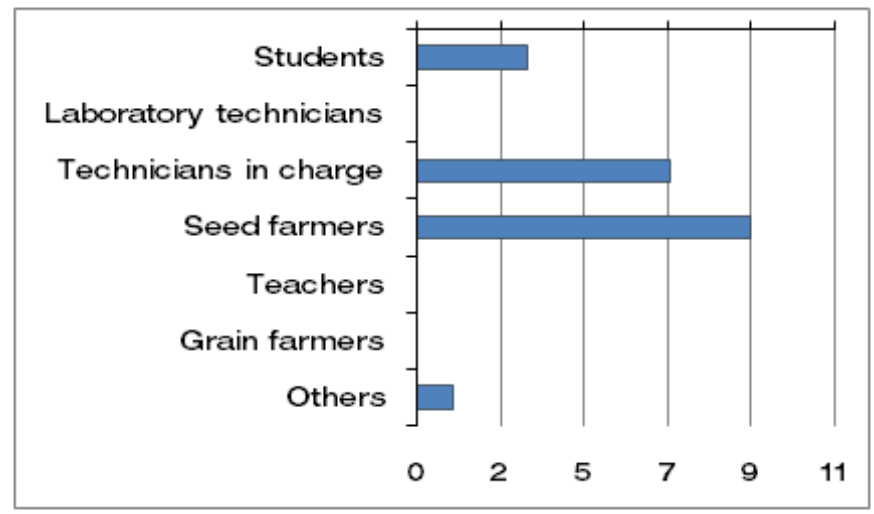

On the question of identifying the sample (Was the sample correctly identified by the client?), $67 \%$ of respondents answered positively, implying that they feel confident on this issue.

On the question of samples traceability (Is your sample easily traceable?), $86 \%$ of responses were positive, showing the system's credibility on this issue and that the customer's needs are met by the procedures adopted.

The samples storage (Do you consider the sample storage adequate?) was performed adequately by $71 \%$ of the respondents, confirming the credibility of the system.

When asked how the samples were prepared for the tests (Are samples prepared to test through automatic means or by hand?), $52 \%$ responded that it was by hand. This may not correspond to reality, because the respondents qualified as "Technician in charge" of SL answered that equipment were employed for this task and students and seed producers respondents "did not know" or answered "by hand". This shows a lack of awareness about this subject and that this should be identified as an issue to be worked further to make the procedures within the SL better known.

Asked if they had knowledge about the training of employees of SL (Are lab's workers trained?), 100\% responded positively.

In the item about laboratory services scope (Is it enough the scope of tests offered by SL?), $76 \%$ responded that they are fully met.

Furthermore, asked about critical points the answers were based ontests performance (What do you consider as critical points in SL's tests?). The tests performed on an SL are mainly biologically based tests, for example, the germination test. There are several critical points in this type of test. Currently for the care of these critical points, SL must follow the requirements of the Rules for Seed Analysis - RAS (BRASIL, 2009). The most critical point indicated by answers was the temperature with $43 \%$ of answers, but $38 \%$ of answers described other issues such as: training, architectural conditions of work and seriousness; tetrazolium salt and $\mathrm{pH}$ tests, temperature and humidity monitoring, and electricity. These responses demonstrate that this are another customer's need that should be more studied, because most of laboratories do these tests so this knowledge must be communicated to the client as well as their criteria for minimization of these critical points. This will show that laboratories are taken care of their needs and becoming more reliable.

The majority of respondents (76\% of answers) consider that equipment (Are your tests made in calibrated equipment?), that the tests are performed is properly calibrated.

Figure 10 shows the SL storage profile (Where is the sample storage?). This technology such as cold rooms and cold and dry rooms are being used on a large scale, but still demonstratethat roomtemperature conditionsoften used are not the most appropriate. AlthoughRules RAS (BRASIL, 2009) suggests an air conditioned environment, but it is not required; even though people in charge knows the environmentis not appropriate, theyhold on because the rules not enforceit.

Figure 5. Profile of sample' storage in a SL

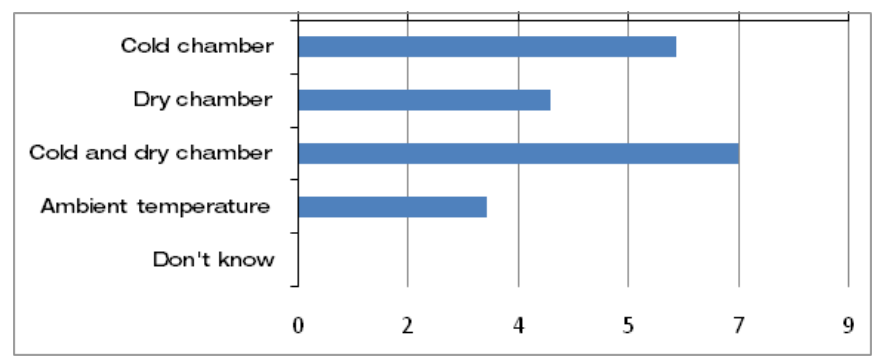

When asked about the period of storage of samples (How long is the sample storagedin your SL?), 29\% of respondents reported ignoring the subject and $71 \%$ of them gave the most diverse answers as six months, ten months, one year, two years and so on, indicating that 
this issue needs planning and logistics within an SL.

A number of respondents (38\% of answers) are unaware of how the sample is discarded and the remainder answers received many responses such as: trash, discard companies, and samples become grain.

In the question about critical analysis (What is the criteria used by critical analysis in your sample?), RAS tolerance tables are the most commonly used criterion in the critical analysis of the results of tests performed in SL.

In the comments about satisfaction in emission time of the results showed that $24 \%$ of respondents were dissatisfied, which is the most critical customer's needs identified in this study.

Although this survey points out some problems in the operation of SLs as shown above, no previous studies in this field were found in the bibliography. Therefore, it is difficult to value the results by comparing them with ones obtained in other countries or even to estimate a time line of quality increase in this service. At the same time, the uses of quality systems show that seed area are seeking a way to evaluate and improve these issues.

\section{CONCLUSIONS}

The data show that life cycle is an effective and alternative tool to identify the needs of customers in seed laboratories that it is important and hard when it is used ISO 17025.

It was possible to identify internal and external customers and they are mostly from seed laboratories affiliated by official government.
The most important customer's need verified was that almost a quarter (24\%) of the seed laboratories customers are dissatisfied with the time of emission of test results.

\section{REFERENCE}

ASSOCIAÇÃO BRASILEIRA DE NORMAS TECNICAS. ABNTNBR ISO/IEC 17025: Estabelece requisitos gerenciais e técnicos para a competência de laboratórios em fornecer resultados de ensaio e calibração tecnicamente válidos. INMETRO 2005.

BRASIL.Ministério da Agricultura, Pecuária e Abastecimento. Regras para Análise de Sementes. Secretaria de Defesa Agropecuária. Brasília: Mapa, 2009. 399 p.

CARVALHO, N.M.; NAKAGAWA, J. Sementes: ciência, tecnologia e produção. 3. ed. Campinas: Fundação Cargill, 1988.424p.

JURAN, J.M. Quality control handbook. New York. : McGraw Hill book Company.1989.

LOURO, L.O.; SOUZA, C.R.V.; BORGES, L.S. Gestão de processos relativos ao produto: Gestấo da qualidade integrada em laboratórios de ensaios - ISO 17025 e BPL. In:ENCONTRO NACIONAL DE ENGENHARIA DE PRODUÇĀO,22,2002. Curitiba. Anais... Curitiba: ABEPRO, 2002. p.1-8.

PESSOA, E.; MARTINS, M.. Revisitando a teoria do ciclo do produto. R. Econ. contemp., Rio de Janeiro, v.11, n.2, 2007. p.307-329.

REIS, A.V.; MENEGATTI, F.A.; FORCELLINI, F.A. O uso do ciclo de vida do produto no projeto de questionários. In: CONGRESSO BRASILEIRO DE GESTÃO DE DESENVOLVIMENTO DE PRODUTOS, 4., 2003, Gramado. Anais... Porto Alegre: FEENG, 2003. 10 p.

REIS, A.V.; FORCELINI, F.A. Identificaçáo de requisitos de clientes para o projeto de um dosador de precisáo para sementes miúdas. Eng. Agríc., Jaboticabal, v.26, n.1, 2006.p.309-320.

SUDMAN, S.; BRADBURN, N. M. Asking questions: a practical guide to questionnaire design. San Francisco: JosseyBass Publishers.1982. 397p.

WESTKÄMPERA, E.; ALTINGB, A. Life Cycle Management and Assessment: Approaches and Visions Towards Sustainable Manufacturing (keynote paper). CIRP Annals- Manufacturing Technology, v.49, n.2, 2000.p.501-526. 